\title{
Event, currere, and the ignorant schoolmaster
}

\author{
Silvia Morelli ${ }^{1}$
}

Accepted: 14 December 2020 / Published online: 8 February 2021

(C) UNESCO IBE 2021

\begin{abstract}
The Covid-19 pandemic has transformed the higher education systems in ways that make visible problems that already existed but that previously were not fully noticed. The pandemic can be understood as an event that inspired social and subjective reflection aimed at a redefinition of the university curriculum. The closure of universities, which began as a preventive measure, has forced professors to reorganize their work through virtual methods and environments. The teaching methods required during the pandemic have eliminated professors' centrality at the university. However, the change from a face-to-face model to a virtual one is not the core problem; rather, the problem is how professors and students can turn the new forms for their relationship into opportunities for emancipation.
\end{abstract}

Keywords Event $\cdot$ Currere $\cdot$ Ignorant schoolmaster $\cdot$ Covid-19 pandemic $\cdot$ University curriculum

The viral outbreak interrupts this common sense and causes the sense of security to melt overnight. We know that the pandemic is not blind and that it has its preferred targets. With it, however, a common awareness of planetary, democratic-like communion is somehow being created.

Boaventura de Sousa Santos (2020, p. 23)

As I write this article, I am in isolation in the city of Rosario, Argentina. My home is a den that protects me from the outside world, from other people, from strangers, and from exposure. It is a space where those I do not want to enter cannot enter, where I can clearly differentiate the private from the social. However, right now, my computer camera has become like an immense door that opens to the world, so that "anyone", in the words of Rancière (2006), can enter my house. As I write this article, I acknowledge that home has

Silvia Morelli

silviatmorelli@gmail.com

1 Facultad de Humanidades y Artes Rosario, Universidad Nacional de Rosario, Entre Ríos 758, S2000CRN Rosario, Santa Fe, Argentina 
become a metaphor for preservation. \#StayHome has the ambiguous meaning of both taking care of and protecting myself from death and also of isolating myself so I can take care of others. I cannot get over my astonishment at how the Covid-19 pandemic has spread across the planet, without permission or apology, leaving no area free from its virulence. It has moved across the world with the speed at which an airplane travels from one city to another. Completely amazed, I watch the outbreak of this global health crisis, while the value of human life is questioned and the relationship between health and the economy has become increasingly tense.

In the world devastated by Covid-19, some issues that already existed but were not noticeable have risen to the surface. As we consider the relationship between the global and the local, we see these issues exacerbated in every corner of the planet. In the case of Argentine society, social isolation exposes and makes more visible the neglect of elders, violence against women, and the indifference toward the deprivation in which some social groups survive. In this crisis, which has generated tension between indifference and solidarity, and between prevention and sensitivity, the university curriculum has been forced to change direction and redefine itself. Based on the evidence of something new that was previously invisible, I recognize this as an "event" (Morelli 2016). In this unexpected crisis, the changing curriculum can be used to shed light on the relationship between education and society, textbooks, and technologies.

Thinking of the curriculum as an event implies the existence of unprecedented issues that have burst onto the local social scene. When something whose existence was unnoticed suddenly comes onto the stage, dealing with it becomes inevitable. The irruption is such that it disrupts the existence of what was considered ordinary. It causes an impact on subjective experience, and thus addressing it becomes imperative. Otherwise, continuing with daily life would become unbearable. Like anything that is addressed in an emergency, this event affects us as subjects, causing a mutation in our subjectivity. Therefore, after this event, we will no longer be the same. Learning, rupture, change, dislocation, opportunity, creativity-these effects of the event place it in a unique and unexpected setting, turning the crisis into possibility. The emergency that revealed what exists becomes an imperative for resilience. In view of the Covid-19 pandemic, the curriculum makes visible the decrease in professors' centrality, suspends the materiality of institutions, reveals the need for digital devices in teaching and learning, and confirms the need for an education based on empathy and solidarity.

Using the framework of this pandemic, which has caused a collapse of norms with respect to safety and whatever we consider to be ordinary, I will pay special attention to the loss of professors' centrality caused by the use of virtual campuses. To analyze the complexity of the present moment, I will consider the "philosophy of the event", as discussed by Badiou $(2013,2015)$ and Lazzarato (2010). The limitation inherent in the concept of an event, which is always located in the present moment, is complemented by Pinar's (2011, 2012, 2014) concept of currere. The recognition of currere in the subjectivity of university teachers allows for analysis from the past, which is manifested in the present and is projected toward the future. The onto-epistemological relationship between event and currere puts the post-foundational thought of the "eventual turn" into a dialogue with the phenomenology in which currere is inscribed. It raises, on the one hand, a conceptual complementarity between event and currere, since the latter allows us to enhance the subjective horizon of professors. On the other hand, it allows for an epistemological complementarity in which post-foundationalism makes currere transcend its edges, going beyond the margins of phenomenology. The Covid-19 pandemic understood as an event in the university curriculum is the common thread of the text. Both the concept of event and that of currere derive from Rancière's (1991) “ignorant schoolmaster" metaphor. This can be used 
to guide the intellectual emancipation of university teachers, in both subjective and social tasks. This combination of event, currere, and the ignorant schoolmaster lets me join in a hybrid dialogue with Badiou, Lazzarato, Pinar, and Rancière as one possible discourse for curriculum studies.

Rancière (1991) analyzed the experience of Joseph Jacotot (2008), whom he calls the "ignorant schoolmaster". Reading this, I allow myself to think of equality, ignorance, and emancipation as the emergencies this event demands we attend to. When the materiality of the classroom disappears, we, as professors, must redefine our teaching identities. We must overcome our resistance as we turn to video conferencing as the means best suited to replace what has been lost, and to disguise the anguish we feel as we try to reconcile the emptiness of our classrooms.

My fellow university teachers of undergraduate and graduate programs are helping me understand what is happening now that the pandemic has forced universities to close their doors and has forcefully encouraged use of the virtual campus. It is in this new scenario that we say, "Attendance is irreplaceable", "A class is not replaced with virtual spaces", "We can't properly take attendance", "The virtual modality is not for everyone", and "We can't properly evaluate our students". My colleagues are also helping me understand that considering the Covid-19 pandemic as an event highlights the centrality of the professor, as well as the many changes that have had an impact on the curriculum, leading it toward hybridity and creativity.

\section{Curriculum and event}

Idealized, the educator becomes a magician, mandated to a pull a rabbit out of a hat.

William Pinar (2012, p. 44)

When universities in Argentina closed their doors to comply with the social, preventive, and compulsory isolation that later became a quarantine, we university teachers from the South were ready to start the 2020 academic year. It should be remembered that the latter runs from March to November, and that we learned on the day it began, with much surprise, that our work, as we had planned it, would be impossible. How were we going to continue being university teachers without traveling to the faculty premises, without entering a classroom, without meeting our colleagues, without replying to students' queries? How were we going to explain what our subject was about, administer exams, develop theories, or propose practical exercises? Was the year 2020 lost before it began? Or was it we, the professors, who were lost and whose daily lives were altered?

If there is any certainty amid so much confusion, it is that, in the words of Badiou (2013, 2015) and Lazzarato (2010), the Covid-19 pandemic presents itself as an event. The philosophy of the event describes a way of facing a new social scenario that is unexpected and that brings uncertainty, discomfort, and instability. In other words, when a social scenario is disrupted by an event, the certainties, routines, and everyday life that kept it organized are lost. This is accompanied by the question "What is happening?" and triggers the idea that another world, not considered until then, is possible (Lazzarato 2010, p. 43). For the subjects to recognize it as an event, it must produce mutations in their subjective experience, causing none of them to be the same from that moment forward. According to Lazzarato (2010, p. 69), an event is an unpredictable, unforeseeable, and risky process and is 
always private. It affects a group of people, in their lives, in their practices and ideas. An event is never global. Although Covid-19 is a worldwide phenomenon, it is up to groups of individuals to define the impact this disease is causing on their lives. It can be said that an event relates the social aspects to the process of subjectivization of those who feel affected by it. Regarding subjectivity, Badiou (2015) recognized three "subject figures" generated at different moments of the event. The first is the "faithful subject", who brings the past into the present. When the pandemic broke out, we, as professors, had our ways of recognizing and enlivening the university curriculum. We were faithful to the centrality we enjoyed in the curricular setting, which was granted by our presence. The second figure is that of the "reactive subject", who acknowledges being disturbed by what is happening. We, as professors, reacted to the suspension of our physical presence, caused by the pandemic; however, within the disturbance of the emergency, we recognized the possibility of change. The third figure is that of the "obscure subject", who does not know what will occur after the event. Although we assume the challenge of devising ways of working that were not considered until now, we also assume the ignorance of not knowing what will happen after the disorder caused by the emergency.

We, Argentine university teachers in the city of Rosario, see how our institutional daily life, our work as faculty, and our relationships with our students are threatened. Only with invention and creativity will we be able to overcome the dislocation and deconstruction caused to all of us by this event. Lazzarato (2010) understood an event as an opening to the possible, in the sense that it is possible that something we never imagined would happen will happen; it is possible that the material aspect of our university life has been lost and that we will now meet in virtual environments. To demonstrate the magnitude of the change produced by an event, he compared it to falling in love. Lazzarato (2010) used falling in love as a metaphor to understand what is happening and how to make room for something new. It is true that falling in love takes us by surprise. With sensitivity, our values are altered, and this allows us to understand that our life will no longer be the same. In a practical sense, it was not in our annual engagement book, yet we make time for our love life; we make it coexist with the rest of our activities, many of which were planned in advance.

To open up to what is possible is to receive, as when one falls in love, the emergence of a discontinuity in our experience, and to build, based on the mutation of sensitivity that the encounter with the other person has generated, a new relationship, a new agency. One falls less in love with the person than with the possible world that they express; in the other, their updated existence is less grasped than the new life possibilities that the encounter has given rise to. (p. 49)

Lazzarato is not the only one who compared an event to falling in love. Badiou (2015) also considered falling in love as the most direct and authentic way of understanding what an event is. Furthermore, he claimed that when two people fall in love, they give rise to an unthinkable and unpredictable possibility. But that does not mean this meeting, by itself, constitutes love. They will have to live something that justifies this unthinkable encounter (Badiou 2013, p. 22).

An event offers important options and possibilities: to discover what is hidden, to imagine the unthinkable, to act upon the unforeseen. We can characterize an event through the subjects for whom and the specific place where it appears. According to Badiou (2013, p. 24), "The event appears only as a creator of possibilities". The fact that the Covid-19 pandemic has caused the suspension of many people's presence in public spaces marks a dramatic change in social settings. This also applies to the university, 
which was emptied from one day to the next and then closed, leaving unattended exam dates and suspending undergraduate and graduate classes that were just beginning. This suspension appeared in the context of mandatory social isolation. It was a matter of vital importance that people be separated in order to avoid a massive spread of the virus. But it is only because of its unique characteristics that this global phenomenon can be considered an event at the university level - that is, when the university admits the possibility of continuing the academic year, which had just begun, through its virtual campus. It is here that the curriculum begins to be a part of this event. What relationship is established between the professors and students? How troubled will they be? How do we, as professors, speak with our students or with our colleagues in the virtual world? In which places do students talk to each other? What visibility do gender, disabilities, and multiculturalism acquire in a virtual curriculum? How do students learn within a virtual university life?

As the synthesis of a faithful, reactive, and obscure subject, I write this article in the middle of complete uncertainty regarding how long the university curriculum will be virtual, how long it will take us to understand this new university life, and what the future of the curriculum will look like. In other words, what new practices will remain in this curriculum when we return to the face-to-face model? To understand what is happening and what shape this new university life might take, I turned to the term currere, coined by Pinar (2011). He said currere is "the running of the course, wherein the curriculum is experienced, enacted and reconstructed" (p. 1). By presenting itself as a verb, it leads the event toward the vivid, toward the experiential, toward processes, and toward action. A currere in virtuality also includes the stories and circumstances of the subjects and institutions. Just like a face-to-face curriculum, a virtual curriculum requires one or more roadmaps and the imagining of possible worlds. I reckon that virtuality also has a currere in which much of its matters are left to the unexpected, to emotions, to identities; as He (2012, p. 46) said, "The student of currere imagines possible futures, including fears as well as fantasies of fulfillment". But the shift from a face-toface model to an ethereal virtual world is not the main issue. The main issue is whether, due to the change in social relations in the university, caused circumstantially by this pandemic, we can observe an event that builds a new curriculum.

For this purpose, I consider currere to be part of this event, helping us with the mutation of sensitivity that the latter causes. Currere, as an allegory of the present, leads to a symbolic analysis of the reality of the event. The powerful thing about this combination of event and currere is that both attend to the relationship between the social and the subjective, so that, in the face of a present circumstance, they both change, and neither the subjective nor the social can be the same thereafter. What the method of currere brings to the event is that it goes beyond the present moment to recover the histories of the past and to reach into the future. As Pinar (2012, p. 33) says, "It is through subjectivity that one experiences history and society, and it is subjectivity through which history and society speak". The relationship between subject and society requires, as this author said, "one's relationship with one's self" and "one's self-reflexive reconstruction of one's subjectivity". This relationship between subjective and social through the method of currere was expressed by Pinar (2012, p. 44) as follows:

The method of currere-the Latin infinitive form of curriculum meaning to run the course, or, in the gerund form, the running of the course-provides a strategy for students of curriculum to study the relations between academic knowledge and life history in the interests of self-understanding and social reconstruction. 
Thinking of the Covid-19 pandemic as a circumstance that triggers an event among those of us at the university leads us to rethink the present and the future of the university as a social institution and of university teachers and students as its subjects. However, we cannot find any answers about how to live in the present of a pandemic if we do not do selfreflection and have the social commitment this entails. As I said before, unlike the event, which asks itself in the present what is happening, currere goes toward the past to reach the future, without neglecting the subject in the present. Self-reflection on what we have been as professors at the university, what we are in the present pandemic circumstances, and what we will be in the future is the process we began to carry out when our university suspended its materiality.

\section{The myth of pedagogy}

Before being the act of the pedagogue, explication is the myth of pedagogy, the parable of a world divided into knowing minds and ignorant ones, ripe minds and immature ones, the capable and the incapable, the intelligent and the stupid.

Jacques Rancière (1991, p. 6)

The event, in the form of something new that bursts into everyday life, is nothing more than what already existed, unnoticed until now, made visible by the degree of disruption it generates. For this reason, a change in sensitivity and subjectivity occurs that means that what was previously tolerated no longer is. Among the many life stories affected by the Covid-19 pandemic, this moment will be sealed in our autobiographies as university participants who work with the curriculum daily will be sealed in this moment. Students live in this moment in quite a different way than we do as professors, which once again confirms the painful thesis about the loss of centrality for our role. The tension between the need to recreate curricular settings without a material aspect and the loss of visibility of teaching leads us to insist on having live meetings with our students, using Zoom, Skype, Facebook Live, or Google Meet. Appealing to the mythological character of Narcissus, who gave Freud (1981) a reason to write about narcissism, I wonder if the computer screen will not be the new mirror in the water surface in which Narcissus admires, fascinated, his own reflection. What happens to our self-admiration if we, as professors, give up our claim to centrality and instead use devices that reject a center-periphery or audience-lectern teaching method?

I think about transmission as a privileged instance of pedagogy, and I think about the times we are going through. During the pandemic, education is not at the forefront of needs and demands. However, although substantial decisions have been made about the healthcare system and the reactivation of what still stands of the Argentine economy, education is changing itself. Reestablishing the pedagogical link becomes a challenge that goes beyond the classic issues of didactics, such as preparing for a class or getting to know the students who comprise it. As I already stated (Morelli 2016, pp. 16-17), pedagogy deals with the link between the professor and the student at the time of transmission. This is an affectionate, ethical, intercultural, transferential, asymmetric, empathic, emotional, and historical bond. Furthermore, it is a gender, racial, religious, institutional, and ideological discourse. There is no transmission without its recognition. But the relationship between the professor and the student is not necessarily established simply by the presence of the former, by specific content, or by the implementation of the didactic triangle. The pedagogical bond is established 
when the other party is recognized as a subject capable of incorporating into the present their intellectual history and their ability to think about themself in the future (Pinar 2011, p. 41) or-as affirmed by Rancière (1991), based on Jacotot (2008)—when masters become emancipated and teach what they do not know. The object of the pedagogical bond is the transmission of culture, biographies, stories, and interpretations. Letting oneself be seen by the other (both the student, who allows themself to be seen by the professor, and vice versa) is necessary in order to be recognized as an intellectual subject. This mutual recognition begins to erase the conditions of professor and student and begins to make their intelligences equal.

At the university level of education, we are both students. Or, better said, at the university, anyone can be a student. By letting ourselves be seen, shortcomings, absences, past experiences, desires, and identities are exposed. This denotes that, although we, as professors, have an important share of responsibility with regard to enabling the pedagogical bond, we are only one of the responsible parties. It is the love and the acknowledgment of the other (i.e., as a student/intelligent entity) that establishes this bond, and without which, there would be no transmission. Or, as Frigerio (2004, p. 20) stated, "Something happens between one subject and another subject, something that exceeds and goes beyond the algorithm of their addition". In other words, for the event in question, neither face-to-face contact nor specific content are essential to enable the pedagogical bond, since something that goes beyond disciplinary knowledge is always transmitted in this relationship. Or at least what is transmitted is something that allows us to analyze, specifically, the content (disciplinary). In this regard, Cornú (2004, p. 27) affirmed,

Transmitting: a name, a last name, an inheritance, knowledge, a history, values, a secret, a message, information, an illness. In the multiple objects that pass from one being to another, and in the various forms they are handed over, some paradoxes are worth highlighting: transmission can be both a conscious act of last will and an unnoticed—and even unknown—-soaking in secrecy. It can be solemn or clandestine. It can be the result of a specific project or of an unpredictable spread.

So, is everything perhaps the object of transmission? What is transmitted? What do we, as professors, allow to be transmitted? What attitudes, values, identifications, and experiences are offered by us, as transmitters, and how much do we allow ourselves to receive from the student? In the pedagogical scenario set by the Covid-19 pandemic, the relationship between us as professors and our students became complicated because the centrality status we had was threatened and even suspended. The isolation caused by Covid-19 placed a new demand on pedagogical relationships: we must listen, let students speak, let students be, and allow students to take the space saved for their imagery. In this regard, I would like to highlight what Cornú (2004, p. 29) said regarding how the building of the subject allows for a pedagogical relationship.

To transmit knowledge is to recognize in another subject the ability to learn that knowledge, to desire it, to understand it, to develop it. "Building" the subject is first to pose/present it as such, to recognize it without trying to create it from head to toe as if it was an object.

The loss of visibility of the condition of professor and the space gained by the condition of student reminds me of Jacotot (1770-1840), the university professor whose story Rancière (1991) told in The Ignorant Schoolmaster. Jacotot was a French revolutionary who was forced into exile in Belgium after the Second Bourbon Restoration. Around 1818, he was appointed by the University of Louvain to teach French. However, because Jacotot did not know the mother tongue of his students, he asked them to read a bilingual edition of Les 
Aventures de Télémaque, by François Fénelon. The students managed to learn the French language, without his explanations. This event allowed him to recognize a teaching method that contemplates the possibility of learning by oneself. What happened to Jacotot is in contrast with the irrefutable thesis that a professor needs students' shortcomings to teach them. In this way, the myth of pedagogy creates students who need their professor's explanations.

Jacotot's (2008) finding that his students learned despite his inability to provide them with explanations revealed the necessary combination of ignorance and emancipation. In this regard, Rancière (1991) pointed out that both conditions allow a student to learn what the professor does not know. Only if the latter is emancipated will they be able to free their student so that student can learn beyond the professor's knowledge. Rancière affirms "one can teach what one doesn't know if the student is emancipated, that is to say, if he is obliged to use his own intelligence" (p. 15). Fate made Jacotot become an emancipated schoolmaster. Like him, we, professors in 2020, realized we had to teach our students in a context that we did not know or that at least was not familiar enough for us to trust. The classroom setting - with our desk, our chair, the blackboard, and the slide projector at the front-was interrupted by an event that was not part of the curriculum. Everything indicated that it was impossible to replace this material aspect of university life. Although we already coexisted with the virtual campus (e.g., with text repositories and digital libraries), the material aspects, in which we felt ourselves to be masters, had not yet been replaced. In this sense, I wonder if it is us who find the event, or if it is the event that finds us. It is only when we face the event that what we have ignored becomes evident—not that we shape it as an explanation, but that we recognize that what we ignored also belongs to the currere. Thus, this ongoing construction (Pinar 2011, 2012, 2014), which is more similar to a verb than to a noun, recognizes the surprise of the event in which autobiography, ignorance, and the unbearable meet in the curriculum studies at the university.

\title{
Teaching to the ignorant or teaching what is ignored?
}

\author{
They didn't know how before, and now they knew how. Therefore, Jacotot had taught \\ them something. And yet he had communicated nothing to them of his science.
}

Jacques Rancière (1991, p. 12)

The synthesis produced between the Covid-19 pandemic and Rancière's (1991) and Jacotot's (2008) pedagogical experiences enables us to think of another image for the professor: one who goes, according to Rancière, from explicator master to ignorant master. Jacotot's experience in the beginning of the 19th century led Rancière to come up with the notion of the ignorant schoolmaster. The latter, through his emancipation, by teaching what he does not know, is transformed from professor into artist:

The revelation that came to Joseph Jacotot amounts to this: the logic of the explicative system had to be overturned. Explication is not necessary to remedy an incapacity to understand. On the contrary, that very incapacity provides the structuring fiction of the explicative conception of the world. It is the explicator who needs the incapable and not the other way around; it is he who constitutes the incapable as such. (Rancière 1991, p. 6) 
Only emancipated professors allow the emancipation of their students. This is how students are able to talk about the art they want to learn. Their emancipation helps us, as ignorant professors, with the suspension of our own voices. We stop explaining how, why, with what purpose, and when, and instead we begin to listen to the art that the student demands and to reflect on the distance we will take in the pedagogical meeting. Although Rancière (1991, p. 5) considered distance part of the explicative system, satirizing about "the art of distance". (I allow myself to disagree with him and incorporate the art of distance into the relationship between the ignorant schoolmaster and the students. In my opinion, the art of distance symbolizes the decision we, as professors, make when confronting students with texts they need to learn without the help of our explanations. The resignation we construct to get away from the role of explainer is an art of distance. This distance will differ, depending on the conditions in which the pedagogical relationship is found. And its form will depend on the art of the ignorant schoolmaster). However, the art of distance is not the same as interest in distance. Every time we, as professors, suspend our interest in the distance between intelligences, we allow students to approach the study and to engage in self-formation. In this way, we stop being explicators and being stultifying, in the words of Rancière (1991, p. 14), and we become emancipated ignorant schoolmasters. As professors, we are circumstance-dependent subjects. Our autobiographies, which are as historical as they are circumstantial, say what we were allowed to learn under certain circumstances. Thus, as is the case with a student, our stories reflect the art we wanted to learn and about which we are able to speak. Furthermore, we are unaware of the power of the knowledge we teach and the possibilities created by what we ignore.

Meanwhile, an explainer can only teach those who do not recognize their emancipation and self-formation. An explaining professor needs to convince their students of those students' own intellectual disability and makes the students depend on the benefits of instruction. For Rancière (1991), this schoolmaster stultifies, stupefies, and experiments by playing with the inequality of intelligences. They play not only with the inequality between their intelligence and that of their students, but also with the inequality of intelligences between students. Rancière added that "the harmonious balance of instruction and moral education is that of a double stultification" (p. 35). We are all intelligent ignorant people who can teach what we do not know. For this reason, Rancière allowed himself to distinguish between the professors who explain and stultify and artists who emancipate by teaching what they do not know.

I believe in the possibility of the event. Without the urgent need to go to the virtual classroom to develop the 2020 academic year, the art of distance would not have arisen and the interest in distance would not have been suspended. In the same way, the method of currere - through its regressive, progressive, analytical, and synthetical moments (Pinar 2012, p. 45)—will lead us to understand our reactions and mutations to this event, as well as our ignorance related to teaching in virtual environments. In Pinar's view, "Allegory embraces both resemblance and difference, the particularity of history and the past's significance for the present moment" (p. 50). To understand curriculum as an allegory "incorporates the past into the present, threaded through one's subjectivity... as working through what in the present requires the continual reactivation of the past" (p. 50). Thus, as an allegory of the present, being an ignorant schoolmaster helps us to analyze who we are now and how we want to teach in our ignorance, as well as who we were as university teachers until the suspension of materiality caused by the pandemic. In present time, without the imperative to use a virtual campus, this disruption of our subjectivity would not have emerged.

The art of distance generates tension between equality and difference. We who teach what we ignore consider all intelligences equal, and that equality allows our students to 
begin, in the words of Rancière (1991, p. 1), an "intellectual adventure". However, higher education is especially fond of inequality, which it tends to justify by resorting to meritocracy. And so the problem is posed backwards. Where equality (of intelligences) must be considered, inequality is noticed, and where difference (of subjects) must be recognized, it is homogenized. Arguing that everyone has intelligence, Rancière (1991) affirmed that these are equal, because the human condition does not distinguish between superior and inferior intelligences. In this equality lies the vote of confidence we as emancipatory professors give our students to implement their art and learn what we do not know:

The artist's emancipatory lesson, opposed on every count to the professor's stultifying lesson, is this: each one of us is an artist to the extent that he carries out a double process; he is not content to be a mere journeyman but wants to make all work a means of expression, and he is not content to feel something but tries to impart it to others. The artist needs equality as the explicator needs inequality. (pp. 70-71)

However, we recognize the differences in every human being. Each of us will recognize the mutation of our subjectivity differently, depending on our self-reflections on the circumstances. When an event surprises us, we, as ignorant schoolmasters, recognize it. As currere proposes, we run our own courses, in different face-to-face or virtual spaces, to play with silence and to define the art of distance. We admit what we ignored, even if we do not know what that ignorance consisted of. We let it emerge as we relax our centrality as professors and suspend the presence of the explicative order. Using the method of currere, we build our own way of marching in the present, during the Covid-19 pandemic. Inspired by Jacotot (2008), who became an emancipator because fate decreed that he had to exile, we understand that fate decreed this pandemic, and thus we recognize ourselves as ignorant and emancipating artists.

At first sight, the idea of the ignorant schoolmaster may leave us perplexed. We may feel an unbearable concern about the possibility of assuming the incompleteness of not knowing. We trusted we were going to start the academic year in a setting that was stable and well known, due to routine. What we never thought would be altered was altered: our university life, or better said, the culture of our university life.

Currere is a process built as one moves forward. It emerges from what is understood in the curriculum and then transforms itself through the subjects, their histories, and their identities. In turn, these subjects are intersected by an institutional history and by the circumstances present in the university. Self-formation and academic knowledge are based on the autonomy students acquire when they can speak about the art they want to learn. We, as ignorant schoolmasters, recognize the currere, and, in the transmission of this autobiographical art, invite students to find their own autobiographies. In the university, to achieve this emancipation, the intersection between academic knowledge and their own histories and circumstances is brought into play. We are never alone in institutional life. As subjects, we are molded by differences in the social and cultural contexts, which also influence the subjective emancipation of the ignorant schoolmaster. As such, the currere will have an impact on university education on a subjective as well as a social level.

The mixture of currere and emancipation makes it essential to think about the curriculum for university careers in a setting where prescriptions and securities are no longer valid. The quarantine time we are living in warns us that it is imperative to make visible what already exists, including citizen training that is sensitive to solidarity. As ignorant schoolmasters, we will have to teach what we do not know, while other schoolmasters will have to become ignorant. However, every one of us will teach our students resilience so they can continue in a world that will never be the same. In the virtual space, each of us 
will face the challenge of transmitting the understanding that "the classroom becomes, simultaneously, a civic square and a room of one's own" (Pinar 2012, p. 47) in any of the forms in which it is presented.

\section{We will no longer be the same}

I leave raised the question of how our subjectivity as university teachers is changing in our current scenario, which places us as reactive and obscure subjects, and where the only thing that can be confirmed is that we will not be the same again. When the event asks what is happening, we are perplexed by a world that, at first glance, is unknown to us, but that was clearly already present in our lives. Discovering it invites us to go through a process of self-reflection and to share with others our new findings. Both Lazzarato (2010) and Badiou $(2013,2015)$ affirmed that we would not be the same after an event. This has led us toward emancipation as ignorant schoolmasters and toward the recognition of our own circumstances through currere.

I am satisfied to recognize that I am disturbed by the event of the Covid-19 pandemic and that I have decided to enhance my reflections with currere. I recognize that, if these two concepts had not been related, my analysis would have been limited to the relationship between the social and the subjective. Looking instead through the tones of the self-from a present that contains the marks of the institutional past and the sufficient potential to imagine a future - enriches the very idea of an event. But, as Frigerio (2004) maintained, "something goes beyond the algorithm of an addition", and so the phenomenological notion of currere is enhanced when it is assumed within the uncertainty of an event. All subjective analysis is colored by the circumstances of the discourse we engage in as university teachers. The allegory of the present, which is the image of a pandemic that produces emancipated ignorant schoolmasters, fuses this event into its own running of the course.

We, as professors, believe that universities will continue to respond to social changes. As intellectual adventurers, we hope to navigate turbulent seas in ships that remain still despite the undulation of the waves. But when an event disrupts our subjectivity, we are no longer the same. Then, the uncertainty facing us reminds us of Rancière (1991) rescuing an ignorant Jacotot (2008). As if we were students again, we plunge into the subjective adventure of recognizing that we can teach without explaining, that equality is an inalienable human condition, that difference is constitutive in each subject, and that each of our students can speak about the art they want to learn.

This is what currere is all about. It traces an endless path on which there are no guarantees. Currere, existing in a continuous present, is an event that plays with our explanations and arts. In the instability of the present, the past always sustains us, and something about the future is always visible. The future is as unstable and precarious as the present, but imagination, hope, and commitment ensure it will be worth living.

When the pandemic ends and we return to the materiality of the university, we will no longer be the same. We will have learned that the past is an inheritance we resist, but also that we value the ability of that inheritance to support us in the turbulence of the present. We will recognize that the curriculum will never again be global; that it will be permanently and pervasively affected by what has occurred; and that our most difficult assignment will be the construction of the art of distance that allows others to become students, emancipated, and artists, in spite of us. The traditional solidity of the university building has vanished into thin air, inviting us as professors to build a new university 
life-one that restores both who we were and who we can be, from the chaos of our present circumstances.

\section{References}

Badiou, A. (2013). La filosofia y el acontecimiento [Philosophy and the event]. Buenos Aires: Amorrortu. Badiou, A. (2015). El ser y el acontecimiento [Being and the event]. Buenos Aires: Bordes Manantial.

Cornú, L. (2004). Transmisión e institución del sujeto. Transmisión simbólica, sucesión, finitud [Transmission and institution of the subject. Symbolic transmission, succession, finitude]. In G. Frigerio, \& G. Diker (Eds.), La transmisión en las sociedades, las instituciones y los sujetos. Buenos Aires: Novedades Educativas-CEM.

de Sousa Santos, B. (2020). La cruel pedagogía del virus [The cruel pedagogy of the virus]. Buenos Aires: CLACSO.

Freud, S. (1981). Introducción al narcisismo [Introduction to narcissism]. In Obras completas (vol. 2). Madrid: Editorial Biblioteca Nueva. (Original work published in 1914).

Frigerio, G. (2004). Los avatares de la transmission [The avatars of transmission]. In G. Frigerio \& G. Diker (Eds.), La transmisión en las sociedades, las instituciones y los sujetos. Buenos Aires: Novedades Educativas-CEM.

Jacotot, J. (2008). Lengua materna [Mother tongue] (P. Ires, Trans.). Buenos Aires: Cactus. (Original work published in 1820).

Lazzarato, M. (2010). Políticas del acontecimiento [Politics of events]. Buenos Aires: Tinta Limón.

Morelli, S. (2016). Recuperando la enseñanza [Recovering teaching]. In S. Morelli (Ed.), Núcleos interdisciplinarios de contenidos. Rosario: Homo Sapiens Editores.

Pinar, W. (2011). The character of curriculum studies. New York, NY: Palgrave Macmillan.

Pinar, W. (2012). What is curriculum theory? New York, NY: Routledge.

Pinar, W. (2014). La teoría del curriculum [Curriculum theory]. Madrid: Narcea.

Rancière, J. (1991). The ignorant schoolmaster. Stanford, CA: Stanford University Press.

Rancière, J. (2006). Política, policía y democracia [Politics, police, and democracy]. Santiago de Chile: LOM Ediciones.

Publisher's Note Springer Nature remains neutral with regard to jurisdictional claims in published maps and institutional affiliations.

Silvia Morelli is Professor of Curriculum Studies and Didactics at Universidad Nacional de Rosario (UNR), in Argentina. She is the head of the School of Educational Sciences at the Faculty of Humanities and Arts, in the UNR. Her research focuses on curriculum policy, teaching content, and curriculum-Didaktik. In 2011 she founded the Centre for the Study and Research of Curriculum and Didaktik (CEICyD) at the UNR. She was Director of Curriculum Development and Academic Relationships at the Ministry of Education of Santa Fe (2013-2019). In 2019 she was elected as a member of the Journal and Publication Committee of the American Association for the Advancement of Curriculum Studies (AAACS), and in 2020 as Argentinian member at the General Assembly of the International Association for the Advancement of the Curriculum Studies. 